\title{
Molecular characterization of cucumber mosaic virus isolates infecting tomato in Hamedan and Tehran provinces of Iran
}

\author{
M. SAFAEIZADEH ${ }^{1,2}$, A. SAIDI ${ }^{1}$, P. PALUKAITIS
}

\begin{abstract}
${ }^{1}$ Department of Biotechnology, Faculty of New Technologies and Energy Engineering, Shahid Beheshti University, G.C., Tehran, Iran; ${ }^{2}$ Zürich-Basel Plant Science Center, University of Basel, Department of Environmental Sciences, Botany, Part of the Swiss Plant Science Web, CH-4056 Basel, Switzerland; ${ }^{3}$ Department of Horticultural Sciences, Seoul Women's University, Seoul, 139-774, Republic of Korea
\end{abstract}

Received December 12, 2014; accepted April 29, 2015

\begin{abstract}
Summary. - Here we identified four isolates, MS, 3H, 50A, and $2 \mathrm{~K}$ of cucumber mosaic virus (CMV) infecting tomato, on the basis of their non-coding intergenic region and a part of the coat protein $(\mathrm{CP})$ sequence in the CMV genomic RNA3. The sequences from the four isolates were compared with other previously characterized isolates of CMV isolated from different plant species across the globe. Sequence comparisons revealed that the two CMV isolates from Hamedan province (MS and $3 \mathrm{H}$ ) had the highest sequence identity with CMV-G10 (98\%), which was previously reported as a severe Hellenic tomato isolate of CMV, while the CMV isolates from Tehran province, including CMV-2K (isolated from Karaj region) and CMV-50A (isolated from Varamin region), had the highest sequence identity with that of CMV-ALF (99\%). Phylogenetic analysis of the nucleotide sequences showed that CMV-MS and CMV-3H belong to group IB, while CMV-2K and CMV-50A belong to group IA. This is the first report on the molecular characterization of novel isolates of CMV infecting tomato plants in Iran.
\end{abstract}

Keywords: cucumber mosaic virus; tomato; phylogenetic analysis

\section{Introduction}

Cucumber mosaic virus (CMV, the genus Cucumovirus, the family Bromoviridae), is regarded as one of the most important plant viruses, both economically in reducing crop yields (Scholthof et al., 2011) and also as a model for plantvirus evolution (Roossinck, 2001; Jacquemond, 2012). CMV infects more than 1,200 plant species in over 100 families of monocots and dicots (Palukaitis et al., 1992; Palukaitis and García-Arenal, 2003; Tomofumi and Satoshi, 2012). The core genome of CMV consists of three positive-sense RNAs referred as RNAs 1, 2, and 3 in a decreasing order of their size (about 3357, 3050 and 2216 nt, respectively), with five open reading frames. Each genomic RNA is packaged

E-mail: safaeezadehmehdi@gmail.com; phone:+41-77-9134743. Abbreviations: $\mathrm{CMV}=$ cucumber mosaic virus; $\mathrm{CP}=$ coat protein in separate particles (Palukaitis et al., 1992; Tomofumi and Satoshi, 2012).

While RNA1 encodes only one protein, namely the la protein, which contains methyl transferase and helicase motifs and functions as a viral component of the replicase complex together with the 2 a protein encoded by RNA2 is an RNA-dependent RNA polymerase (Hayes and Buck, 1990; Roossinck et al., 1999; Roossinck, 2001). RNA2 also encodes the $2 \mathrm{~b}$ protein, which functions in host-specific long-distance movement (Ding et al., 1994, 1995), symptom severity (Ding et al., 1996), and suppression of post-transcriptional gene silencing (Brigneti et al., 1998). RNA3 encodes 2 proteins: the $3 \mathrm{a}$ and $3 \mathrm{~b}$ proteins. The $3 \mathrm{a}$ protein is a cell-to-cell movement protein (MP) and $3 b$ protein is the coat protein $(\mathrm{CP})$ which is involved in several processes including virus assembly, cellto-cell and vascular movement (Suzuki et al., 1991; Canto et al., 1997), and also aphid-mediated transmission (Palukaitis 
et al., 1992; Palukaitis and García-Arenal, 2003). Based on the results from several approaches, including: serological studies, peptide mapping, nucleic acid hybridization and sequence similarity, the CMV isolates can be divided into two main groups, I and II (Palukaitis et al., 1992; Roossinck 2002; Tomofumi and Satoshi, 2012). Group I, can be further divided into two clusters designated as IA and IB.

The molecular analysis and determination of the phylogenetic status of viruses is one of the most important steps towards the elucidation of the virus epidemiology and is necessary for the control of plant viral diseases, by introducing appropriate varieties for cultivation by farmers. In this paper, we determine the genomic sequences of the non-coding intergenic region and a part of the CP gene from RNA3 of four CMV isolates obtained from naturally infected tomato in Iran.

\section{Materials and Methods}

Virus isolates. Four CMV isolates were obtained from tomato (Solanum lycopersicum) plants showing mosaic, yellowing and shoestring symptoms. Two isolates were from Hamedan province (CMV-MS and CMV-3H isolated from Bahar and Tuyserkan regions, respectively) and the other two isolates were from Tehran province (CMV-2K and CMV-50A isolated from Karaj and Varamin regions, respectively). Detection of CMV was done with polyclonal antibodies obtained from Bioreba AG (Switzerland) using DASELISA according to Clark and Adams (1977) and the manufacturer's instructions. All buffers, reagents, positive and negative controls were obtained from Bioreba AG. Infection by CMV was confirmed by bioassays on herbaceous plants. Briefly, the infected leaf samples were initially propagated on Nicotiana tabacum $\mathrm{cv}$. Samsun followed by at least three single local lesion passages on Chenopodium amaranticolor leaves. Infection of N. tabacum cv. Samsun plants by CMV was confirmed by DAS-ELISA and RTPCR. The infected extracts reacted in the DAS-ELISA only with CMV antibodies and not with any other viral antibodies including arabis mosaic virus, potato virus $Y$, tomato bushy stunt virus, tomato yellow leaf curl virus and tomato spotted wilt virus. The inoculated plants were maintained in an insect-proof greenhouse at standard conditions $\left(15-25^{\circ} \mathrm{C}\right)$.

Total RNA extraction and RT-PCR. Total RNA was extracted from $75 \mathrm{mg}$ of the symptomatic parts of the leaves using TRI-Reagent (Sigma, USA) according to the manufacturers' protocol and the extracted RNA was resuspended in $50 \mu \mathrm{l}$ of diethylpyrocarbonate (DEPC)-treated sterile $\mathrm{H}_{2} \mathrm{O}$. RNA quality and concentration were determined by gel electrophoresis in $1 \%$ agarose gel. As a negative control, the total RNA extracted from healthy tomato was used.

Highly specific oligonucleotide primers designed and described by Blas et al. (1994) were used to amplify the conserved sequences of CMV RNA3 (yielding 540 bp fragment) by RT-PCR. The sequences of the primers used were, forward primer: 5 -
GTAATACGACTCACTATAGGTTTTGTTTG-3', complementary to position 114 to 132 in the $\mathrm{CP}$ gene, and the reverse primer: 5'-GCGCGAAACAAGCTTCTTATC-3', homologous to nucleotides 633 to 653 in the non-coding intergenic region (MWGBiotech. Co., Germany).

The cDNAs were synthesized using RevertAid ${ }^{\mathrm{TM}} \mathrm{M}-\mathrm{MuLV}$ reverse transcriptase (Fermentas, Germany) at $42^{\circ} \mathrm{C}$ for one hour, using $0.5 \mu$ l of RNase inhibitor. An aliquot $(2.5 \mu \mathrm{l})$ of the RT reaction was used for PCR in a final volume of $25 \mu$ l. The PCR was performed using a thermal cycler (Eppendorf-AG 22331, Germany), with an initial denaturation step of $95^{\circ} \mathrm{C}$ for 5 min followed by 35 cycles of denaturation at $95^{\circ} \mathrm{C}$ for $60 \mathrm{sec}$, annealing at $42^{\circ} \mathrm{C}$ for $60 \mathrm{sec}$ and an extension at $72^{\circ} \mathrm{C}$ for $60 \mathrm{sec}$. The PCR products and DNA ladder (GeneRuler ${ }^{\mathrm{TM}} 250$ bp DNA Ladder Plus, Fermentas, Lithuania) were analyzed by electrophoresis in $1 \%$ agarose gel, in the presence of 1 $\mu \mathrm{g} / \mathrm{ml}$ ethidium bromide using $1 \mathrm{x}$ Tris-Borate EDTA (TBE) buffer (Sambrook et al., 1989).

Sequencing and phylogenetic analysis. The RT-PCR products of the four CMV isolates, MS, $3 \mathrm{H}, 2 \mathrm{~K}$ and $50 \mathrm{~A}$, were verified by sequencing (MWG-Biotech AG, Germany). The sequencing of PCR fragments was done in both orientations, using the primers used for initial PCR amplification. Comparison of the nucleotide sequences was done using Blast software with other sequences available in the GenBank (NCBI, USA) to identify related sequences (Altschul et al., 1997).

Sequence assembly, multiple sequence alignments and phylogenetic analyses were carried out using MEGA software (Molecular Evolutionary Genetics Analysis) version 5.0 (Tamura et al., 2011). A neighbor-joining phylogenetic tree was constructed after 1,000 replicates of bootstrapping of the aligned sequences and all branches with bootstrap values $<60 \%$ were collapsed. The sequences of CP genes of peanut stunt virus (PSV strain ER; Acc. No. U15730.1) and tomato aspermy virus (TAV; Acc. No. AJ550020.1) were used as outgroups.

\section{Results and Discussion}

The results of RT-PCR analyses using specific primers to detect CMV were in complete agreement with DAS-ELISA results. A PCR product of $\sim 540$ bp was obtained from infected samples and no amplicon was produced from healthy plant extracts.

The nucleotide sequence analysis of the amplified fragments of the four CMV isolates (Acc. No. HQ659502.1, JF343523.1, JF343522.1, JF343524.1 for the isolates MS, 3H, $2 \mathrm{~K}$, and $50 \mathrm{~A}$, respectively) by Blast search revealed a high homology to the already published sequences of CMV.

However, there was remarkable sequence variation within the isolates obtained in this study. The CMV-MS and $\mathrm{CMV}-3 \mathrm{H}$ sequences revealed a nucleotide identity of $98 \%$ with CMV-G10 and CMV-G2, (Acc. No. AY541691.1 and AY450854.1, respectively), two Greece isolates of CMV that 


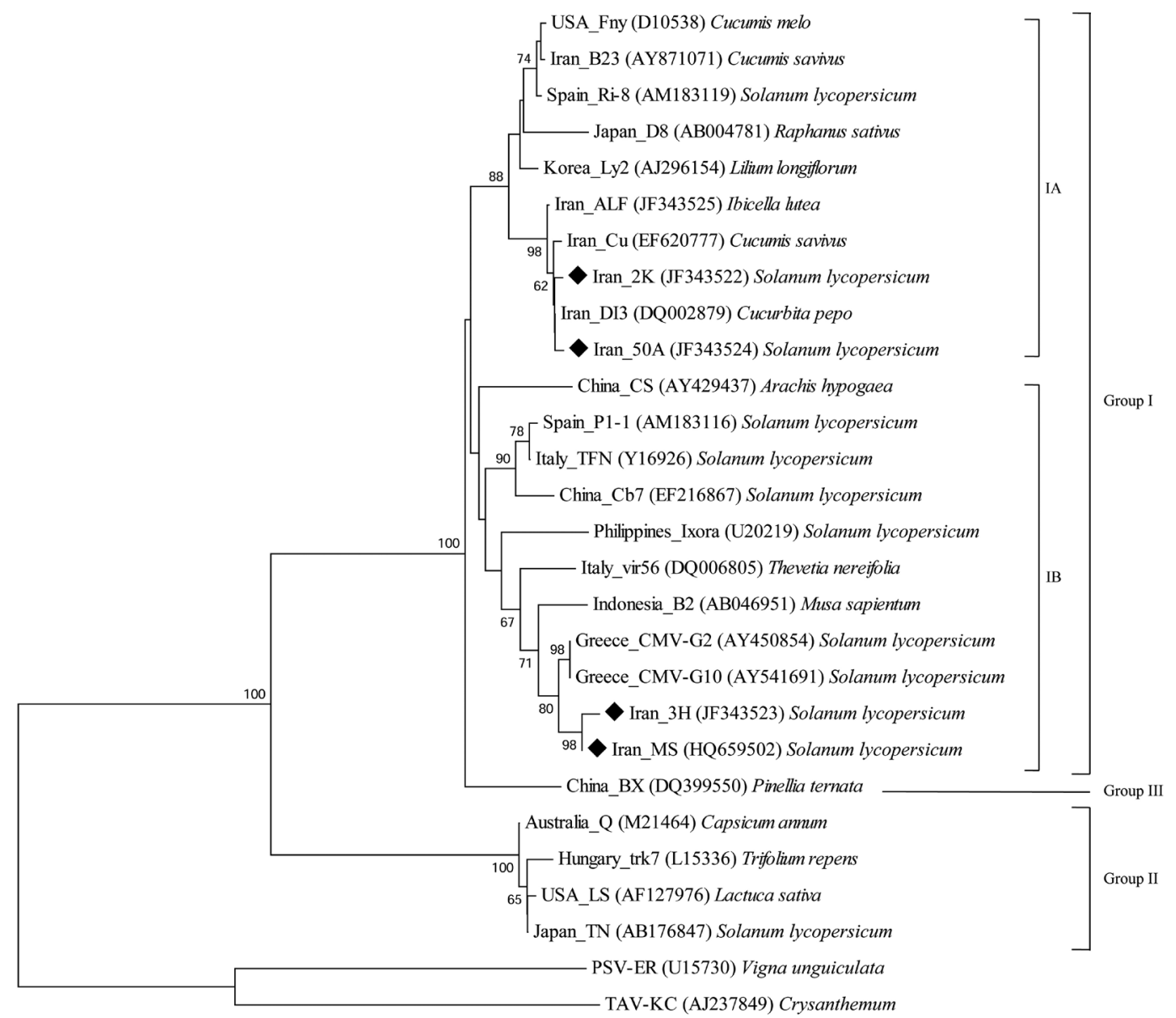

Fig. 1

Phylogenetic analysis from partial nucleotide sequences of non-coding intergenic region and a part of the CP gene in RNA3, obtained with MEGA version 5.0, of $26 \mathrm{CMV}$ isolates, including four isolates from Iran

Iranian isolates studied in this research are marked by diamonds (MS, $3 \mathrm{H}, 50 \mathrm{~A}$ and $2 \mathrm{~K}$ ). Sequences for comparison were obtained from GenBank and the affiliation of each isolate, group IA, group IB, group II, and group III is also indicated.

were isolated from tomato and reported as severe strains of CMV (Sclavounos et al., 2006). Phylogenetic analysis showed that isolates obtained from Hamedan province belong to the group IB in the same cluster with the Greece isolates (Fig. 1). On the other hand, CMV-2K revealed the highest homology with 99\% identity to CMV-ALF (Acc. No. JF343525.1), which was reported in Ibicella lutea (Safaeizadeh and Saidi, 2012), and also 99\% identity to CMV-Cu (Acc. No. EF620777.1), which was isolated from cucumber (Rasoulpour and Izadpanah, 2008). CMV-50A revealed a nucleotide identity of 99\% to CMV-ALF (Acc. No. JF343525.1), and also 99\% identity to CMV-DI13 (Acc. No. DQ002879.1), which was isolated from squash in the north-west of Iran. As illustrated in Fig. 1, CMV-2K and CMV-50A belong to the group IA, in the same cluster with CMV-ALF. The fact that CMV-2K and CMV-50A have sequence homology with CMV-ALF, which was reported in I. lutea, a weed host in vegetable crops, indicates that I. lutea may play an important role in CMV epidemiology in the studied area. However, there were some variations among these isolates and further sequencing of the other regions of the CMV genome, like the movement protein gene will provide more information about these isolates.

Based on the molecular analysis done for these novel isolates in this study, it is certain that the primers described by Blas et al. (1994) are sensitive, quick and easy to use for diagnostics of CMV. The use of a single pair of CMV-specific primers and sequencing the PCR product offers a fast and accurate means of grouping different CMV isolates. As illustrated in the phylogenetic tree (Fig. 1), sequencing of the non-coding intergenic region and the part of $\mathrm{CP}$ gene can strongly discriminate the CMV isolates and determine their 
phylogenetic status. The fact that CMV-MS and CMV-3H have similar sequence homology, suggests that the isolates from Hamedan province have originated from a common source. Bashir et al. (2008) also showed that all the CMV isolates obtained from cucurbit in the northwest of Iran belong to group IA. Additionally, in one of the earlier reports by Bashir et al. (2006), the CMV isolates from cucumber showed that group IA and II occur in the northwestern regions of Iran. In another study which was carried out in northern regions of Iran (Hosseinzadeh, et al., 2012), the presence of group I and II was determined in different hosts, but their results were based just on serological studies.

In the current study, we report for the first time, that viruses of tomato from Hamedan province cluster in group IB. Since CMV-3H and CMV-MS have highest sequence similarity with CMV-G2 and CMV-G10 which formerly were reported from Greece (Sclavounos et al., 2006); it is hypothesized that CMV-IB might be transported through agricultural products from Mediterranean countries to Iran. It is also hypothesized that CMV-3H and CMV-MS might have biological properties as reported for CMV-G2 and CMV-G10. Anyhow, subsequent studies are needed to determine biological properties of the isolates which are reported in this study.

Recently, Liu et al. (2009) reported that CMV sequences could be clustered in to three different groups. They showed that the CMV-BX isolated from Pinellia ternate belongs to group III. As illustrated in Fig. 1 our phylogenetic analysis is in complete agreement with their results.

The information about phylogenetic and genetic diversity reported here will provide insights in to the studies on evolution, gene function and plant-virus interaction of CMV and other related viruses. Altogether, our results will be useful in the formulation of future control strategies of the viruses infecting tomato. Overall, molecular studies of a large number of additional CMV isolates from different plant hosts and different regions are required to determine the phylogenetic status of CMV isolates from Iran.

Acknowledgements. The authors wish to thank Shahid Beheshti University research fund for supporting the project. We thank Pascal Mäser (University of Basel) for assisting in sequence data analysis, N. Shahraeen (Iranian Research Institute of Plant Protection-IRIPP) for critical reading of the manuscript, Dominik Klauser (University of Basel; Syngenta Foundation for Sustainable Agriculture) for very helpful advices and reading the manuscript. We wish to thank A. Mansouri for taking care of the plants and other colleagues at the department of Biotechnology.

\section{References}

Altschul SF, Madden TL, Schäffer AA, Zheng J, Zhang Z, Miller W, Lipman DJ (1997): Gapped BLAST and PSI-BLAST: a new generation of protein database search programs. Nucleic Acid Res. 25, 3389-3402. http://dx.doi.org/10.1093/ nar/25.17.3389

Bashir N, Kalhor M, Zarghani S (2006): Detection, differentiation and phylogenetic analysis of cucumber mosaic virus isolates from cucurbits in the northwest region of Iran. Virus Genes 32, 277-288. http://dx.doi.org/10.1007/ s11262-005-6912-2

Bashir N, Nematollahi S, Torabi E (2008): Cucumber mosaic virus subgroup IA frequently occurs in the northwest Iran. Acta Virol. 52, 237-242.

Blas CDe, Borja MJ, Saiz M, Romero J (1994): Broad spectrum detection of cucumber mosaic virus (CMV) using the polymerase chain reaction. J. Phytopathol. 141, 323-329. http://dx.doi.org/10.1111/j.1439-0434.1994.tb01476.x

Brigneti G, Voinnet O, Li WX, Ji LH, Ding SW, Baulcombe DC (1998): Viral pathogenicity determinants are suppressors of transgene silencing in Nicotiana benthamiana. EMBO J. 17, 6739-6746. http://dx.doi.org/10.1093/ emboj/17.22.6739

Canto T, Prior DAM, Hellwald KH, Oparka KJ, Palukaitis P (1997): Characterization of cucumber mosaic virus IV. Movement protein and coat protein are both essential for cell-tocell movement of cucumber mosaic virus. Virology 237, 237-248. http://dx.doi.org/10.1006/viro.1997.8804

Clark MF, Adams AN (1977): Characteristics of the microplate method of enzyme-linked immunosorbent assay for the detection of plant viruses. J. Gen. Virol. 34, 475-483. http://dx.doi.org/10.1099/0022-1317-34-3-475

Ding SW, Anderson BJ, Haase HR, Symons RH (1994): New overlapping gene encoded by the cucumber mosaic virus genome. Virology 198, 593-601. http://dx.doi.org/10.1006/ viro.1994.1071

Ding SW, Li WX, Symons RH (1995): A novel naturally occurring hybrid gene encoded by a plant RNA virus facilitates long distance virus movement. EMBO J. 14, 5762-5772.

Ding SW, Shi BJ, Li WX, Symons RH (1996): An interspecies hybrid RNA virus is significantly more virulent than either parental virus. Proc. Natl. Acad. Sci. USA 93, 7470-7474. http://dx.doi.org/10.1073/pnas.93.15.7470

Hayes RJ, Buck KW (1990): Complete replication of a eukaryotic virus RNA in vitro by a purified RNA-dependent RNA polymerase. Cell 63, 363-368. http://dx.doi. org/10.1016/0092-8674(90)90169-F

Hosseinzadeh H, Nasrollanejad S, Khateri H (2012): First report of cucumber mosaic virus subgroups I and II on soybean, pea, and eggplant in Iran. Acta Virol. 56, 145-148. http:// dx.doi.org/10.4149/av $2012 \quad 02 \quad 145$

Jacquemond M (2012): Cucumber mosaic virus. Adv. Virus Res. 84, 439-504. http://dx.doi.org/10.1016/b978-0-12-3943149.00013-0

Liu YY, Yu SL, Lan YF, Zhang CL, Hou SS, Li XD, Chen XZ, Zhu XP (2009): Molecular variability of five cucumber mosaic virus isolates from China. Acta Virol. 53, 89-97. http:// dx.doi.org/10.4149/av 2009 0289

Palukaitis P, García-Arenal F (2003): Cucumoviruses. Adv. Virus Res. 62, 241-323. http://dx.doi.org/10.1016/s0065-3527(03)62005-1 
Palukaitis P, Roossinck MJ, Dietzgen RG, Francki RIB (1992): Cucumber mosaic virus. Adv. Virus Res. 41, 281-348.

Rasoulpour R, Izadpanah K (2008): Properties and taxonomic position of hoary cress strain of cucumber mosaic virus. J. Plant Pathol. 90, 97-102.

Roossinck MJ (2001): Cucumber mosaic virus, a model for RNA virus evolution. Mol. Plant Pathol. 2, 59-63. http://dx.doi. org/10.1046/j.1364-3703.2001.00058.x

Roossinck M J, Zhang L, Hellwald K (1999): Rearrangement in the nontranslated region and phylogenetic analyses of Cucumber mosaic virus RNA3 indicate radial evolution of three subgroups. J. Virol. 73, 6752-6758.

Roossinck MJ (2002): Evolutionary history of Cucumber mosaic virus as deduced by phylogenetic analyses. J. Virol. 76, 3382-3387. http://dx.doi.org/10.1128/JVI.76.7.33823387.2002

Safaeizadeh M, Saidi A (2012): First report of Cucumber mosaic virus on Ibicella lutea in Iran. J. Plant Pathol. 94 (4), S4.85-105.

Sambrook S, Fritch EF, Maniatis T (1989): Molecular Cloning: A Laboratory Manual. 2nd edn., Cold Spring Harbor Laboratory Press, New York, USA.

Scholthof KG, Adkins S, Czosnek H, Palukaitis P, Jacquot E, Hohn H, Hohn B, Saunders K, Candresse T, Alquist P, Hemen- way C, Foster G (2011): Top 10 plant viruses in molecular plant pathology. Mol. Plant Pathol. 12, 938-954. http:// dx.doi.org/10.1111/j.1364-3703.2011.00752.x

Sclavounos AP, Voloudakis AE, Arabatzis C, Kyriakopoulou PEA (2006): Severe Hellenic CMV tomato isolate: symptom variability in tobacco, characterization and discrimination of variants. Eur. J. Plant Pathol. 115, 163-172. http:// dx.doi.org/10.1007/s10658-006-0010-8

Suzuki M, Kuwata S, Kataoka J, Masuta C, Nitta N, Takanami Y (1991): Functional analysis of deletion mutants of cucumber mosaic virus RNA3 using an in vitro transcription system. Virology 183, 106-113. http://dx.doi. org/10.1016/0042-6822(91)90123-S

Tamura K, Peterson D, Peterson N, Stecher G, Nei M, Kumar S (2011): MEGA5: Molecular evolutionary genetics analysis using maximum likelihood, evolutionary distance, and maximum parsimony methods. Mol. Biol. Evol. 28, 2731-2739. http://dx.doi.org/10.1093/ molbev/msr121

Tomofumi M, Satoshi TO (2012): Cucumber mosaic virus: viral genes as virulence determinants. Mol. Plant Path. 13, 217-225. http://dx.doi.org/10.1111/j.1364-3703 .2011.00749.x 